\title{
Penyesuaian Diri dan Coping Strategy pada Pekerja Seks Komersial yang Terinfeksi Infeksi Menular Seksual
}

\section{Putu Tania Lita Devi and Supriyadi}

Program Studi Psikologi, Fakultas Kedokteran, Universitas Udayana tanialita_devi@rocketmail.com

\begin{abstract}
Abstrak
Bekerja sebagai pekerja seks komersial sangat dekat dengan berbagai risiko, salah satu konsekuensinya adalah tertular infeksi menular seksual. Dampak yang ditimbulkan dari penyakit ini dapat mempengaruhi pekerja seks baik secara fisik maupun psikologisnya, sehingga pekerja seks komersial perlu yang namanya penyesuaian diri untuk bisa menyesuaikan diri dengan keadaan diri serta lingkungannya. Penyesuaian diri yang positif memerlukan yang namanya strategy coping, adapun strategy coping dibagi menjadi dua, emotional focused dan problem focused coping. Penelitian ini bertujuan untuk mengetahui adanya hubungan antara penyesuaian diri dengan strategy coping pada pekerja seks komersial yang terinfeksi infeksi menular seksual.

Subjek dalam penelitian ini adalah 87 orang perempuan pekerja seks komersial yang berlokasi di Denpasar yang berusia antara 20-55 tahun. Instrumen yang digunakan dalam penelitian ini adalah skala penyesuaian diri serta skala coping strategy yang telah diuji validitas serta reabilitasnya, yaitu skala penyesuaian diri dengan nilai $\operatorname{rxx}=0,977$ dan skala coping strategy $\mathrm{rxx}=0,934$.

Hasil korelasi Pearson's product moment menunjukan angka korelasi sebesar 0,655 dengan taraf signifikansi sebesar 0,000 menunjukan bahwa ada hubungan yang positif antara penyesuaian diri dengan coping strategy, sedangkan nilai R2 sebesar 0,429 menunjukan bahwa variabel penyesuaian diri dapat menjelaskan variabel coping strategy sebesar $42,9 \%$.
\end{abstract}

Kata Kunci : Penyesuaian Diri, Coping Strategy, Infeksi Menular Seksual, Pekerja Seks Komersial

\begin{abstract}
Worked as commercial sex workers is very close to a variety of risks as a consequence, one of them is infected with a sexually transmitted infections. The impact of the disease can affect the sex workers from physical and psychological, so they need an adjustment to be able to adjust to the situation and their environment. Positive adjusment requires something named coping strategy, coping strategy is divided into two, first called emotional focused and second called problem focused coping. This study aims to research the relationship between adjustment and coping strategy in commercial sex workers infected sexually transmitted infections.
\end{abstract}

Subjects in this study were 87 commercial sex workers in Denpasar area, between the age 20-55 years old. The instrument of this research is the scale of adjustment and scale of coping strategy that has been tested for validity and reability, the scale of adjusment value $\operatorname{rxx}=0,977$ and scale of coping strategy value $\operatorname{rxx}=0,934$.

Results of Pearson's product moment correlations show a correlations of 0,655 with a significants level 0,000 indicates there's positive relationship between the adjustment to the coping strategy, while the R2 value of 0,429 indicates that the variable can explain the variable adjustment to variable coping strategy by $42,9 \%$.

Keywords: Adjusment, Coping Strategy, Sexually Transmited Infections, Commercial Sex Workers. 


\section{P. T. L. DEVI DAN SUPRIYADI}

\section{LATAR BELAKANG}

Prostitusi bukan merupakan sebuah fenomena baru yang ada di dunia ini khususnya di Indonesia, kegiatan prostitusi nyatanya telah muncul sejak zaman kerajaan, kegiatan prostitusi sendiri tidak lepas dari kebudayaan patriarki yang dulunya berkembang di Indonesia yang lambat laun memunculkan definisi sosial bahwa perempuan adalah objek seksual, bahkan pada zaman itu perempuan dianggap sebagai hadiah atau objek paling berharga yang dapat diberikan seseorang kepada rajanya (Prastiwi, 2007).

Zaman penjajahan nyatanya tidak membuat kegiatan prostitusi berhenti, bahkan kegiatan prostitusi mengalami peningkatan pada saat zaman penjajahan Belanda yang saat itu dipimpin oleh J.P.Coen yang langsung mendatangkan germo dari Perancis dan China serta mendatangkan para pekerja seksnya dari Macao dengan tujuan untuk menghibur para tentara Belanda, sekaligus digunakan sebagai tempat persinggahan bagi orang-orang China kaya pada saat itu (Republika, 2003).

Dilihat di era serba maju seperti sekarang, nyatanya praktik prostitusi justru berkembang semakin pesat, hal tersebut disebabkan oleh banyak faktor antara lain, demi menghindari kesulitan hidup atau istilahnya mengambil "jalan pintas" untuk memenuhi kondisi ekonomi, lalu arus urbanisasi yang semakin tinggi menyebabkan sulitnya mencari pekerjaan di kota-kota besar, sedangkan faktor lainnya terjadi akibat aspirasi materiil yang tinggi pada wanita-wanita yang menyukai barang-barang mewah namun memiliki penghasilan kurang memadai/malas bekerja, sehingga perempuan-perempuan itu memutuskan untuk bekerja di dunia prostitusi (Kartono, 2011).

Ada banyak istilah yang digunakan dalam penyebutan perempuan-perempuan pekerja seks, antara lain cewek orderan, pelacur, sundal, wanita tuna susila, serta pekerja seks komersial, setiap nama-nama tersebut sebenarnya memiliki nama yang sama hanya beberapa dibuat untuk memperhalus panggilan mereka sehingga terlihat lebih manusiawi (Prastiwi, 2007). Koentjoro (2004), pekerja seks komersial merupakan bagian dari kegiatan seks di luar nikah yang ditandai oleh kepuasan dari beberapa orang dan bertujuan untuk mendapatkan imbalan sebagai sumber pencaharian.

Pekerja seks komersial jumlahnya kini terus meningkat setiap tahun, bahkan menurut hasil statistik diperkirakan sampai dengan tahun 2013 jumlah PSK yang tersebar di berbagai lokalisasi yang ada di Indonesia telah mencapai jumlah yang fantastis, yaitu kurang lebih sekitar 40.000 orang, hal ini cukup mengkhawatirkan karena sulitnya dalam memangkas jumlah PSK yang dari hari ke hari jumlahnya semakin meningkat (Tempo, 2013).

Sulitnya memangkas fenomena ini dikarenakan masih banyaknya pro-kontra mengenai kegiatan prostitusi, beberapa pihak merasa bahwa prostitusi merupakan perbuatan tercela, kotor, melanggar nilai-nilai agama namun di pihak lain justru merasa diuntungkan dengan adanya kegiatan ini, bahkan tidak sedikit yang menggantungkan hidupnya pada pekerjaan sebagai pekerja seks untuk menghidupi diri sendiri maupun orang terdekat, walaupun dengan berbagai risiko yang harus pekerja seks tersebut hadapi.

Risiko yang harus pekerja seks hadapi sebenarnya cukup beragam, mulai dari pengucilan di lingkungan sosial, stigma-stigma sosial yang harus mereka dapatkan, seperti cemoohan, pelecehan yang dilakukan terhadap mereka, bahkan sampai yang membahayakan yaitu terinfeksi infeksi menular seksual dan HIV/AIDS. Infeksi menular seksual dapat dijelaskan sebagai infeksi yang menyerang manusia melalui transmisi hubungan seksual, seks oral, dan seks anal (Wikipedia, 2014).

Infeksi menular seksual atau yang biasa disingkat dengan IMS memiliki berbagai macam jenis penyakit yang dapat dikategorikan masuk di dalamnya, antara lain Gonorhoe, Sfillis, Herpes Genitalis, Kondiloma, Vaginosis Bacterial, kondilomata Kandidosis Vulvovaginal, Ulkus Mole, Trikomoniasis, Limfogranuloma Venerum, serta HIV/AIDS. Penyakit-penyakit tersebut tidak dapat disepelekan, karena memiliki dampak antara lain kerusakan alat reproduksi, kerusakan syaraf, menularkan pada bayi dalam kandungan serta yang terburuk dapat menyebabkan kematian (Herawati, 2007).

Pengetahuan yang cukup terkait kesehatan reproduksi tentunya harus dimiliki oleh pekerja seks untuk menghindari infeksi menular seksual, apalagi pekerjaan sebagai pekerja seks memiliki risiko tinggi akan hal tersebut. Pengetahuan yang cukup harus dibekali pula dengan kesadaran diri dari pekerja seks untuk memproteksi dirinya, sehingga dapat mencegah atau setidaknya meminimalisir risiko dari pekerjaannya. Adapun hal-hal yang pekerja seks dapat lakukan antara lain, selalu menggunakan kondom ketika berhubungan seks dengan pelanggan, menjaga kebersihan organ seksual, serta secara rutin memeriksakan diri ke dokter (KPAN, 2010).

Faktanya, di lapangan masih banyak pekerja seks yang tidak melakukan hal tersebut sehingga penularan infeksi menular seksual menjadi sulit untuk di hindari, hal tersebut dinilai menjadi penyebab mengapa jumlah kasus infeksi menular seksual semakin hari semakin meningkat di Indonesia. Peningkatan tersebut tercermin dari data Departemen Kesehatan RI tahun 1997-1998 yang menyebutkan terdapat sebanyak 13.000 kasus infeksi menular seksual pada tahun 1997, sedangkan meningkat menjadi 20.420 kasus infeksi menular seksual pada tahun 1998 (Sari, 2012). Data statistik terbaru dari UNICEF bahkan lebih mengejutkan, disana disebutkan bahwa terdapat 100.000 kasus baru di tahun 2011 di Indonesia yang 3 peringkat teratasnya 
diduduki oleh daerah-daerah berikut Papua (serta Papua Barat), Bali, dan Jakarta.

Di Bali sendiri khususnya di Denpasar, menurut Koordinator Yayasan Kerti Praja, Bapak Dewa Nyoman Suyetna menyebutkan ada sekitar 3000 pekerja seks komersial dan $20 \%$ diantaranya positif terinfeksi infeksi menular seksual serta HIV/AIDS (Pikiran Rakyat, 2013). Dilihat dari data Dinas Kesehatan Provinsi Bali 2012 dapat dilihat sebaran infeksi menular seksual paling banyak terdapat di daerah Denpasar yaitu sebanyak 6.454 kasus pada laki-laki dan perempuan (Suarjaya, 2013), hal inilah yang peneliti jadikan pertimbangan mengapa memilih Denpasar sebagai lokasi penelitian.

Terinfeksi IMS atau infeksi menular seksual dengan kondisi sebagai seorang pekerja seks akan berpengaruhi terhadap berbagai lini dalam kehidupan orang tersebut, baik dari sisi psikis maupun psikologisnya. Dinas Kesehatan Provinsi Bali Tahun 2011 menyebutkan dampak fisik dari infeksi menular seksual adalah menurunkan kualitas ovulasi sehingga akan mempengaruhi siklus menstruasi serta kesuburan, peradangan alat reproduksi di organ yang lebih tinggi sehingga dapat menyebabkan kehamilan di luar rahim, melahirkan anak dengan cacat bawaan, kanker leher rahim, bekas bisul/nanah di daerah alat kelamin yang dapat memengaruhi kepuasan dalam berhubungan seksual, nyeri sewaktu buang air kecil, gangguan neurologi, lebih mudah terifeksi HIV/AIDS, serta kemandulan (Kristina, 2014).

Dampak psikologis yang akan ditimbulkan apabila seseorang terinfeksi infeksi menular seksual menurut Dinas Kesehatan Provinsi Bali tahun 2011 adalah munculnya perasaan rendah diri, malu dan takut sehingga tidak mau berobat atau bahkan mencoba mengobati sendiri dengan obatobatan/dosis yang tidak tepat, gangguan dalam berhubungan seks, bahkan stres yang berkepanjangan tak jarang pula berakibat depresi karena harus kehilangan pekerjaan (Kristina, 2014).

Dampak psikologis serta fisik yang diakibatkan oleh IMS akan membuat pekerja seks menghadapi tuntutantuntutan serta perubahan-perubahan dalam kehidupannya, sehingga pekerja seks pun dituntut untuk berusaha untuk mencari cara-cara yang berorientasi pada tindakan intrapsikis, sehingga mampu melalui hal-hal diatas, dimana cara-cara tersebut disebut dengan coping strategy (Lazarus \& Folkman, 1991).

Menurut Lazarus dan Folkman (1991), coping strategy dapat dijelaskan sebagai proses dimana individu mencoba mengelola jarak yang ada di antara tuntutan-tuntutan, baik itu yang berasal dari individu maupun tuntutan yang berasal dari lingkungan dengan sumber-sumber daya yang individu gunakan dalam situasi menghadapi stres.

Pearlin dan Schooler (1987) menyebutkan bahwa coping merupakan suatu respon (perilaku atau persepsi kognitif) terhadap ketegangan hidup eksternal yang bertindak untuk mencegah, menghindari, atau mengontrol distress emosi. Pendekatan coping strategy dapat dibagi menjadi 2 bentuk, yang pertama adalah emotional focused coping, yaitu meregulasi respon emosional terhadap suatu masalah, dan lebih sering terjadi ketika penilaian individu menyatakan bahwa tidak ada hal lain yang bisa dikerjakan untuk mengubah kondisi lingkungan yang merugikan atau merubah stressor. Pekerja seks dengan IMS yang memilih emotional focused coping akan berada pada kondisi mengatur atau meregulasi keadaan emosinya terkait penyakit yang individu derita, sehingga coping ini lebih mengacu kepada bagaimana individu memelihara harapan dan optimisme menyangkut fakta yang harus dialaminya (Dian, 2008)

Bentuk coping yang kedua adalah problem focused coping merupakan bentuk coping yang menggunakan cara mengatur, atau mengubah masalah yang menyebabkan tekanan, hambatan, dengan menggunakan sumber-sumber yang ada pada diri individu, seperti merubah tingkat aspirasi, mencari cara lain untuk kepuasan, atau mempelajari ketrampilan baru, hal ini menurut Pearlin dan Schooler (1987). Individu yang menggunakan bentuk coping strategy ini ketika menghadapi stress event yang dalam hal ini terinfeksi infeksi menular seksual (IMS) akan mencari cara-cara agar bisa sembuh dari penyakit atau setidaknya mengurangi dampak dari penyakitnya, seandainya ada pekerja seks yang memutuskan untuk berhenti bekerja sebagai pekerja seks, maka pekerja seks tersebut akan berusaha untuk mempelajari ketrampilan baru guna menyambung perekonomian yang dapat digunakan sebagai bekal hidup (Dian, 2008).

Coping strategy dapat disimpulkan sebagai proses dimana individu mencoba mengelola jarak yang ada di antara tuntutan-tuntutan, baik itu yang berasal dari individu maupun tuntutan yang berasal dari lingkungan dengan sumber-sumber daya yang individu gunakan dalam situasi menghadapi stres agar mampu menyesuaikan diri dengan lingkungannya, seperti yang dijelaskan oleh Lazarus dan Folkman (1991). Hal tersebut sesuai dengan pendapat White dan Watt (1981) yang mengatakan bahwa coping strategy merupakan bagian dari strategi adaptasi atau penyesuaian diri.

Penyesuaian diri adalah kemampuan individu untuk dapat meleburkan diri dengan keadaan sekitarnya, atau individu dapat mengubah lingkungannya menjadi sesuai dengan keadaan serta sesuai dengan keinginan yang diharapkan individu yang bersangkutan (Walgito, 1991). Pendapat serupa diungkapkan oleh Fahmi (1982), yang menjelaskan bahwa penyesuaian diri adalah suatu proses yang meliputi respon mental serta tingkah laku, dimana individu berusaha keras agar mampu mengatasi konflik serta frustrasi karena terhambatnya kebutuhan dalam diri, sehingga mampu mencapai keselarasan serta keharmonisan antara tuntutan dalam diri dan tuntutan yang berasal dari luar dirinya. 


\section{P. T. L. DEVI DAN SUPRIYADI}

Penyesuaian diri yang dilakukan oleh pekerja seks mengarah kepada keadaan yang harus mereka lakukan guna menjalani kehidupan yang lebih baik, karena sudah hukum alam bahwa manusia hidup ditengah perubahan, sehingga untuk bertahan manusia harus mampu menyesuaikan diri dengan lingkungannya.

Selain melihat paparan dari teori-teori diatas, sebelumnya peneliti juga telah melakukan studi kasus terhadap seorang pekerja seks komersial dimana dari studi kasus tersebut peneliti mendapatkan fakta bahwa pekerja seks yang tidak terinfeksi infeksi menular seksual saja telah menghadapi berbagai tekanan terkait pekerjaannya, sehingga ini memperkuat asumsi peneliti bahwa pekerja seks komersial yang terinfeksi infeksi menular seksual akan lebih banyak mendapatkan "preasure" baik yang berasal dari dalam diri individu mapupun lingkungannya sehingga strategy coping tentunya akan sangat berperan dalam penyesuaian diri pekerja seks tersebut (Devi, 2014).

\section{METODE PENELITIAN}

\section{Variabel dan Definisi Operasional}

Variabel bebas dalam penelitian ini adalah coping strategy sedangkan variabel terikat dalam penelitian ini adalah penyesuaian diri. Adapun definisi operasional dari masingmasing variabel penelitian adalah sebagai berikut:

1. Coping strategy adalah suatu proses dimana individu mencoba untuk mengelola jarak yang ada antara tuntutantuntutan (baik itu tuntutan yang berasal dari individu maupun tuntutan yang berasal dari lingkungan) dengan sumber daya yang mereka gunakan dalam menghadapi stressfull event.

Terdapat 2 bentuk coping strategy ( Lazarus \& Folkman, 1991), yaitu:

- Emotional Focused Coping adalah usaha untuk mengubah emosi, berdasarkan pengalaman, yang disebabkan oleh peristiwa yang menimbulkan stres dengan aspek perilaku sebagai berikut: pelarian masalah (escapism), pengabaian (minimization), menyalahkan diri sendiri (self-blame), pencarian arti (seeking meaning).

- Problem Focused Coping adalah usaha yang berpusat pada masalah atau situasi yang menyebabkan stres. Orang-orang yang menggunakan strategy coping ini dapat diketahui dari aspek perilaku sebagai berikut: menahan diri (excersized caution), tindakan instrumental (instrumental action), negosiasi (negotiation), dan support mobilization.

2. Penyesuaian diri adalah proses individu dalam mengatasi atau menghadapi tekanan atau tuntutan. Penyesuaian diri juga bukanlah semata-mata aktivitas intelektual untuk memecahkan masalah, namun juga melibatkan perasaan serta emosi ketika lingkungan memunculkan konflik atau ancaman.
Adapun dimensi dalam penyesuaian diri menurut Scheineders (1999) sebagai berikut: absence of excessive emotionality, absence of psychological mechanism, absence of the sense of personal frustrastion, rational deliberation and self-direction, ability to learn, utilization of past experience, and realisticobjective attitude.

\section{Responden}

Pada penelitian ini peneliti menggunakan teknik pengambilan sampel secara cluster (cluster random sampling) yang artinya pengambilan sampel dilakukan secara random, namun yang dirandom hanya clusternya, bukan disaat memilih anggota unit elementer (Nazir, 1988). Subjek yang digunakan adalah pekerja seks komersial perempuan yang berada di lokalisasi di daerah Denpasar dengan rentang usia subjek berkisar antara 20-55 tahun dan memiliki riwayat sedang atau pernah terinfeksi salah satu dari infeksi menular seksual. Jumlah responden pada penelitian ini adalah 78 orang perempuan pekerja seks komersial.

\section{Tempat Penelitian}

Penelitian ini peneliti lakukan sekitar bulan April akhir sampai dengan Mei awal tahun 2015. Pengambilan data dilakukan sebanyak 2 kali yang dilakukan di lokalisasi Y yang terletak di kota Denpasar, Bali.

\section{Alat Ukur}

Pada peneleitian ini menggunakan 2 skala yaitu skala penyesuaian diri yang peneliti buat menggunakan aspek-aspek penyesuaian diri menurut Scheineders (1999), dan skala coping strategy yang peneliti buat menggunakan dimensi coping strategy menurut Lazarus dan Folkman (1991). Skala penyesuaian diri memiliki 27 item sedangkan skala coping strategy memiliki 24 item, yang masing-masinng skalanya terdapat item yang bersifat favorable dan unfavorable. Penilaian terhadap kedua skala tersebut menggunakan metode equal appearing interval, dimana setiap pernyataan yang terdapat di dalam kusisioner memiliki pilihan jawaban ya (Y) dan tidak (T). Individu yang menjawab tidak (T) akan diberikan skor 0 sedangkan apabila menjawab ya (Y) maka, skor yang diberikan akan tergantung dari $Q$ Value dari masing-masing item.

Hasil uji validitas pada skala coping strategy menunjukan jumlah item yang gugur sebanyak 33 item dari total 60 item, dimana item-item yang gugur tersebut memiliki Q Value lebih dari 4, sedangkan pada skala penyesuaian diri menunjukan jumlah item yang gugur sebanyak 14 item dari total 38 item. Reabilitas untuk skala coping strategy sebesar 0,934, sedangkan untuk skala penyesuaian diri sebesar 0,977 , 
dimana skor-skor tersebut didapat menggunakan rumus untuk menghitung reabilitas sebagai berikut:

$$
\begin{gathered}
r x x=\frac{s s^{2}-s e^{2}}{s s^{2}} \\
s s^{2}=\frac{\frac{\Sigma T^{2}}{k}-\frac{(\Sigma i)^{2}}{n k}}{n-1} \\
s e^{2}=\frac{\Sigma i^{2}-\frac{\Sigma R^{2}}{n}-\frac{\Sigma T^{2}}{k}+\frac{(\Sigma i)^{2}}{n k}}{(n-1)(k-1)}
\end{gathered}
$$

\section{Teknik Analisis Data}

Teknik analisis data yang peneliti gunakan untuk menguji hipotesis pada penelitian ini menggunakan uji regresi sederhana dan uji Pearson's Product Moment, yang digunakan untuk menguji hipotesis asosiatif (uji hubungan) dua variabel yang skalanya bersifat interval/ratio (Hasan, 1999), sedangkan untuk menguji normalitas peneliti menggunakan Kolmogorof Smirnov yang bertujuan untuk menguji hipotesa antara dua buah distribusi, apakah populasi memiliki bentuk yang serupa atau tidak (Nazir, 1988). Pengujian linieritas peneliti menggunakan Lagrange multiplier yang bertujuan untuk mengetahui apakah variabel yang diteliti linier atau tidak.

\section{Etika Penelitian}

Melihat dari subjek penelitian dalam penelitian ini termasuk dalam kategori "rawan", maka peneliti tidak lupa untuk mempertimbangkan issue etik terkait penelitian agar nantinya penelitian ini tidak merugikan baik dari pihak peneliti maupun subjek yang diteliti. Adapun kode etik yang telah peneliti penuhi berdasarkan buku Panduan Kode Etik Psikologi Indonesia (2010) adalah:

1. Pasal 46 ayat 2 "Psikolog dan/ilmuwan psikologi memberi perlindungan terhadap hak dan kesejahteraan partisipan penelitian atau pihak-pihak yang terkait".

2. Pasal 47 ayat 1 "Psikolog dan/ilmuwan psikologi harus memenuhi aturan profesional baik dalam perencanaan dan penulisan penelitian yang dalam hal ini mendapat izin dari pemangku wewenang wilayah setempat".

3. Pasal 48 ayat 1 "Psikolog dan/ilmuwan psikologi mengambil langkah-langkah untuk melindungi perorangan atau kelompok yang akan menjadi subjek penelitian"

4. Pasal 48 ayat 3 "Psikolog dan/ilmuwan psikologi harus memberi kesempatan adanya pilihan kegiatan lain kepada partisipan apabila tidak ingin terlibat atau mengundurkan diri dari keikutsertaan pada saat penelitian”.
5. Pasal 49 ayat 1 terkait inform concern "dalam rangka mendapatkan persetujuan dari calon partisipan, psikolog dan/ilmuwan psikologi harus menjelaskan proses penelitiaan secara terperinci"

a. "tujuan penelitian, jangka waktu, hak menarik diri dari keikutsertaan atau mengundurkan diri, keterbatasan, kerahasiaan, insentif untuk partisipan, dan siapa yang dapat dihubungi untuk informasi lebih lanjut"

d."psikolog dan/ilmuwan psikologi berusaha menghindari segala bentuk pemaksaan termasuk daya tarik yang berlebihan agar partisipan ikut serta dalam penelitian".

6. Pasal 50 ayat 1 "Psikolog dan/ ilmuwan psikologi tidak diperkenankan menipu atau menutupi informasi yang mungkin dapat mempengaruhi calon niat partisipan untuk ikut serta".

7. Pasal 51 ayat 3 "Debriefing dalam penelitian dapat ditiadakan jika pada saat awal penelitian telah dilakukan penjelasan tentang sifat, hasil, dan kesimpulan penelitian, agar psikolog dan/ ilmuwan psikologi dapat mengambil langkah tepat untuk meluruskan persepsi yang keliru yang mungkin dimiliki partisipan".

\section{HASIL PENELITIAN}

\section{Karakteristik Subjek}

Berdasarkan hasil pengkategorisasian subjek sebanyak 78 orang pekerja seks perempuan, maka di dapatlah tabel sebagai berikut:

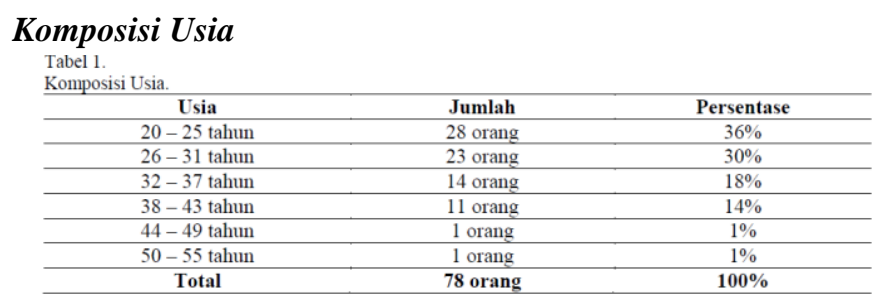

Dari tabel diatas terlihat rentang usia yang mendominasi usia para pekerja seks yang berlokasi di Lokalisasi Y adalah para perempuan dengan usia 20 sampai dengan 25 tahun, sedangkan untuk perempuan dengan usia 44 tahun sampai dengan 55 tahun menjadi jumlah usia minoritas dalam lokalisasi tersebut.

\section{Kategorisasi Skala Coping Strategy}

Tabel dibawah ini akan menunjukkan pengkategorisasian skala coping strategy berdasarkan kecenderungan menggunakan strategy coping tipe emotional focused coping, problem focused coping, atau tipe campuran berdasarkan pengkategorisasian secara statistik menggunakan Z Score: 
Tabel 2

Kategorisasi Skala Coping Strategy

\begin{tabular}{cccc}
\hline Rentang Nilai & Kategori & Jumlah & Persentase \\
\hline Skor emotional $\geq 0,50$ & $\begin{array}{c}\text { Tipe Emotional } \\
\text { Coping }\end{array}$ & 9 & $11,5 \%$ \\
\hline Skor Problem $\geq 0.50$ & $\begin{array}{c}\text { Tipe Problem } \\
\text { Coping }\end{array}$ & 19 & $24,4 \%$ \\
& Tipe Campuran & 50 & $64,1 \%$ \\
\hline $\begin{array}{c}\text { Skor Problem } \geq 0.50 \text { \& Skor } \\
\text { Emotional } \geq 0.50\end{array}$ & & & \\
\hline
\end{tabular}

Berdasarkan tabel diatas dapat dilihat bahwa pekerja seks komersial yang memiliki tipe coping emotional focused hanya sebanyak 9 orang atau sekitar $11,5 \%$, lalu yang memiliki tipe coping problem focused sebanyak 19 orang atau sekitar 24,4\%, dan yang memiliki tipe coping campuran sebanyak 50 orang atau sekitar $64,1 \%$, sehingga dapat disimpulkan bahwa kemampuan coping strategy pekerja seks komersial yang terjangkit infeksi menular seksual di lokalisasi $\mathrm{Y}$ adalah tipe campuran.

\section{Kategorisasi Skala Penyesuaian Diri}

Tabel dibawah ini akan menunjukkan pengkategorisasian skala penyesuaian diri dari kategori rendah, sedang, dan tinggi:

Tabel 3.

Kategorisasi Skala Penyesuaian Diri

\begin{tabular}{cccc}
\hline Rentang Nilai & Kategori & Jumlah & Persentase \\
\hline $121,95>\mathrm{X}$ & Rendah & 10 & $12,8 \%$ \\
\hline $121,95<\mathrm{X} \leq 183,83$ & Sedang & 59 & $75,6 \%$ \\
\hline $183,3<\mathrm{X}$ & Tinggi & 9 & $11,5 \%$ \\
\hline
\end{tabular}

Berdasarkan tabel diatas dapat dilihat bahwa pekerja seks yang memiliki penyesuaian diri rendah adalah sejumlah 10 orang atau $12,8 \%$, lalu yang berpenyesuaian diri sedang sebanyak 59 orang atau sekitar $75,6 \%$ dan yang memiliki penyesuaian diri tinggi sebanyak 9 orang atau jika di persentasekan berjumlah 11,5\%. Berdasarkan hasil kategorisasi dapat disimpulkan bahwa para pekerja seks komersial yang terjangkit infeksi menular seksual di lokalisasi Y memiliki kemampuan penyesuaian diri yang sedang.

\section{Uji Asumsi}

Tabel 4.

Hasil Uji Normalitas Kolmogorov Smirnov

\begin{tabular}{ccc}
\hline Variabel & Kolmogorof-smirnov & $\begin{array}{c}\text { Asymp. Sig. (2-tailed) } \\
\text { (P) }\end{array}$ \\
& & 0,165 \\
\hline Penyesuaian Diri & 1,117 & 0,519 \\
\hline Coping Strategy & 0.816 & \\
\hline
\end{tabular}

1. Sebaran Data Variabel Penyesuaian Diri

Berdasarkan tabel diatas dapat dilihat bahwa variabel penyesuaian diri memiliki nilai kolmogorof-smirnov sebesar $1,117$ serta nilai signifikansi sebesar 0,165 ( $p>0,05)$ yang berarti bahwa terdapat distribusi yang normal pada variabel penyesuaian diri.

2. Sebaran Data Variabel Coping Strategy

Berdasarkan tabel diatas dapat dilihat bahwa variabel coping strategy memiliki nilai kolmogorof-smirnov sebesar $0,816$ serta nilai signifikansi sebesar 0,519 ( $>>0,05)$ yang berarti bahwa terdapat distribusi yang normal pada variabel coping strategy.

\begin{tabular}{ccccc}
$\begin{array}{l}\text { Tabel 5. } \\
\text { Hasil Uji Linieritas Lagrange }\end{array}$ & & & \\
\hline Model & $\mathbf{R}$ & R Square & $\begin{array}{c}\text { Adjusted R } \\
\text { Square }\end{array}$ & Std. Error of the Estimate \\
\hline 1 & $.020^{\mathrm{a}}$ & .000 & -.013 & 23.29699437 \\
\hline
\end{tabular}

Hasil tampilan output pada tabel diatas menunjukkan R2 sebesar 0.000 dengan jumlah n 78, maka besarnya nilai c2 hitung adalah 0 . Nilai ini dibandingkan dengan c2 tabel dengan $\mathrm{df}=70$ dan tingkat signifikansi 0.05 didapat nilai $\mathrm{c} 2$ tabel sebesar 90.5312 dikarenakan c2 hitung lebih kecil dari c2 tabel maka dapat disimpulkan bahwa model yang benar adalah model linear, sehingga kini peneliti dapat melanjutkan ke tahap selanjutnya yaitu melakukan uji hipotesis menggunakan analisis Pearson's product moment.

\section{Uji Hipotesis}

Uji hipotesis pada penelitian ini menggunakan metode uji regresi sederhana dan uji korelasi Pearson's product moment yang akan di jelaskan pada tabel berikut:

\section{Uji Korelasi Pearson's Product Moment}

\begin{tabular}{|c|c|c|c|}
\hline Penyesuaian diri & & Penyesuaian Diri & Coping Strategy \\
\hline & Pearson Corellation & 1 & 0,655 \\
\hline & Sig. (2-tailed) & & 0,000 \\
\hline & $\mathrm{N}$ & 78 & 78 \\
\hline
\end{tabular}

Berdasarkan keterangan pada tabel diatas terlihat bahwa coping strategy dengan penyesuaian diri memiliki angka korelasi sebesar 0,655 dengan taraf signifikansi sebesar 0,000 $(\mathrm{P}<0,05)$. Dari hasil tersebut dapat disimpulkan bahwa terdapat hubungan antara coping strategy dengan penyesuaian diri. Variabel coping strategy dengan variabel penyesuaian diri juga memiliki hubungan yang positif, yang artinya semakin efektif coping strategy seseorang maka akan semakin baik pula penyesuaian dirinya.

\section{Uji Regresi Sederhana

\begin{tabular}{|c|c|c|c|c|}
\hline Model & $\mathbf{R}$ & R Square & $\begin{array}{c}\text { Adjusted R } \\
\text { Square }\end{array}$ & $\begin{array}{l}\text { Std. Error of the } \\
\text { Estimate }\end{array}$ \\
\hline 1 & $.465^{\mathrm{a}}$ & .216 & .206 & 23.30169 \\
\hline
\end{tabular}

Berdasarkan tabel diatas diperoleh nilai $\mathrm{R}$ sebesar 0,465 , hal ini menunjukkan terdapat hubungan yang cukup kuat antara coping strategy dengan penyesuaian diri. 
Berdasarkan tabel diatas diperoleh pula nilai R Square sebesar 0,216. Hal ini menunjukkan sumbangan yang efektif dari variabel coping strategy ke penyesuaian diri sebesar $21,6 \%$.

Tabel 8 .

Hasil Uji Regresi F.

\begin{tabular}{lllrrrr}
\hline Model & & $\begin{array}{l}\text { Sum of } \\
\text { Squares }\end{array}$ & Df & Mean Square & F & Sig \\
\hline 1 & Regression & 11394.758 & 1 & 11394.758 & 20.986 & $.000^{\mathrm{a}}$ \\
\hline & Residual & 41265.627 & 76 & 542.969 & & \\
\hline Total & 52660.385 & 77 & & & \\
\hline
\end{tabular}

\section{Tabel 9 .}

Hasil Uji Regresi t.

Model

\begin{tabular}{llrrrrr} 
& & \multicolumn{4}{c}{ Coefficients } \\
\cline { 2 - 7 } & \multicolumn{1}{c}{ B } & \multicolumn{1}{c}{ Std. Error } & Beta & \\
\hline \multirow{2}{*}{1} & 71.573 & 18.518 & & 3.865 & .000 \\
\cline { 2 - 7 } & Constant) & .429 & .094 & .465 & 4.581 & .000 \\
\hline
\end{tabular}

Dari uji F test didapat F Hitung adalah 20,986, dengan taraf signifikansi 0,000 , oleh karena probabilitas $(0,000)$ jauh lebih kecil dari 0,05 , sehingga model regresi dapat dipakai untuk memprediksi penyesuaian diri, sedangkan $\mathrm{t}=4.581, \mathrm{P}=0.00$, menunjukkan adanya hubungan antara coping strategy dengan penyesuaian diri dimana sifat hubungan adalah kausal (sebab-akibat). Adapun persamaan regresinya sebagai berikut:

\section{$Y=71.573+0,429 X$ \\ Dimana: \\ Y: Penyesuaian Diri \\ $X$ : Coping Strategy}

\section{PEMBAHASAN}

Berdasarkan hasil uji regresi yang peneliti lakukan, didapatkan nilai signifikansi sebesar $0,000 \quad(>0,05)$, hal tersebut menunjukkan bahwa variabel coping strategy dapat memprediksi variabel penyesuaian diri. Hasil dari uji Pearson's product moment yang dilakukan peneliti menyatakan bahwa hipotesis yang peneliti buat diterima. Hipotesis peneliti adalah ada hubungan antara coping strategy dengan penyesuaian diri pada pekerja seks komersial yang terinfeksi infeksi menular seksual. Pada hasil analisis di uji hipotesis di dapatkan korelasi sebesar 0,216 dan taraf signifikansi sebesar 0,000. Taraf signifikansi 0,000 ( $\mathrm{p}<0.005)$ menunjukkan terdapat hubungan antara 2 variabel tersebut dan hubungan tersebut bersifat kausal (sebab-akibat). Koefisien korelasi atau nilai $\mathrm{R}$ selanjutnya dikuadratkan dan didapatkan hasil sebesar 0,216. Hasil tersebut menunjukkan bahwa variabel coping strategy dapat menjelaskan variabel penyesuaian diri sebesar $42,9 \%$.

Hasil uji korelasi Pearson's product moment menunjukkan korelasi sebesar 0,655 dengan taraf signifikansi $0,000 \quad(\mathrm{P}<0,05)$ dimana hal tersebut menunjukkan adanya hubungan antara coping strategy dengan penyesuaian diri dan memiliki hubungan yang positif. Hubungan positif artinya semakain efektif coping strategy seseorang maka akan semakin baik penyesuaian diri individu tersebut.
Pekerja seks komersial adalah wanita yang memiliki kebiasaan melakukan hubungan seksual diluar perkawinan, baik dengan imbalan jasa maupun barang, tidak jarang mereka disebut juga sebagai pelacur menurut Mukarom (2012). Koentjoro (2004) menyebutkan ada 5 alasan seseorang memilih menjadi pekerja seks komersial yaitu materialisme, modelling, dukungan orangtua, lingkungan yang permisif dan faktor ekonomi.

Memilih pekerjaan sebagai pekerja seks komersial tentunya bukan pekerjaan yang bebas dari risiko, justru risiko yang didapat cukup banyak, seperti merusak sendi-sendi kehidupan keluarga, pelanggaran terhadap moral serta norma, pelanggaran terhadap hukum serta agama, dan yang tidak kalah penting kemungkinan untuk penyebaran serta terinfeksi infeksi menular seksual (Setiawan, 2013).

Seorang pekerja seks yang terinfeksi IMS akan mengalami perubahan-perubahan yang mempengaruhi kondisi pekerja seks tersebut baik dari kondisi psikis maupun psikologisnya. Menurut Dinas Kesehatan Provinsi Bali Tahun 2011 dampak fisik dari infeksi menular seksual adalah menurunkan kualitas ovulasi sehingga akan mempengaruhi siklus menstruasi serta kesuburan, peradangan alat reproduksi di organ yang lebih tinggi sehingga dapat menyebabkan kehamilan di luar rahim, melahirkan anak dengan cacat bawaan, kanker leher rahim, bekas bisul/nanah di daerah alat kelamin yang dapat mempengaruhi kepuasan berhubungan seksual, nyeri sewaktu buang air kecil, gangguan neurologi, lebih mudah terifeksi HIV/AIDS, serta kemandulan (Kristina, 2014)

Dampak psikologis yang akan ditimbulkan apabila seseorang terinfeksi infeksi menular seksual menurut Dinas Kesehatan Provinsi Bali tahun 2011 adalah munculnya perasaan rendah diri, malu dan takut sehingga tidak mau berobat atau bahkan mencoba mengobati sendiri dengan obatobatan/dosis yang tidak tepat, gangguan dalam berhubungan seks, bahkan stres yang berkepanjangan tak jarang pula berakibat depresi karena harus kehilangan pekerjaan (Kristina, 2014).

Dampak psikologis serta fisik yang diakibatkan oleh IMS akan membuat para pekerja seks menghadapi tuntutantuntutan serta perubahan-perubahan dalam kehidupan mereka, individu pun dituntut harus berusaha untuk mencari cara yang berorientasi pada tindakan serta intrapsikis sehingga mampu melalui hal-hal diatas, dimana cara-cara tersebut disebut dengan coping strategy (Lazarus \& Folkman, 1991).

Coping strategy dapat dijelaskan sebagai proses dimana individu mencoba mengelola jarak yang ada di antara tuntutan-tuntutan, baik itu yang berasal dari individu maupun tuntutan yang berasal dari lingkungan dengan sumber-sumber daya yang korban gunakan dalam situasi menghadapi stres agar mampu menyesuaikan diri dengan lingkungannya, hal ini dijelaskan oleh Lazarus dan Folkman (1991). 
Penyesuaian diri adalah suatu proses alamiah dan dinamis yang bertujuan mengubah perilaku individu, agar tercipta hubungan yang lebih sesuai antara kondisi diri dengan kondisi lingkungan (Wijaya, 2007). Berdasarkan hasil uji korelasi pearson's product moment, diketahui bahwa korelasi antara Coping strategy dengan penyesuaian diri adalah sebesar 0,655 dengan taraf signifikansi sebesar 0,000, ini menunjukkan bahwa terdapat hubungan antara 2 variabel tersebut, sedangkan skor $\mathrm{R}$ sebesar 0,655 menunjukkan hubungan yang positif.

Arah positif menunjukkan bahwa semakin efektif kemampuan coping strategy seseorang maka semakin baik pula penyesuaian diri orang tersebut, serta sebaliknya semakin tidak efektif kemampuan coping strategynya maka semakin buruk pula penyesuaian diri orang tersebut, hal tersebut sesuai dengan pendapat White dan Watt (1981) yang menyebutkan bahwa coping strategy adalah bagian dari strategi individu untuk melakukan penyesuaian diri atau adaptasi.

Pada karakteristik subjek dapat dilihat bahwa usiausia para pekerja seksual berada di rentang usia 20 sampai dengan 55 tahun. Usia 20-25 tahun berjumlah 28 orang atau berkisar sekitar 36\%, lalu usia 26-31 tahun berjumlah 23 orang (30\%), usia 32-37 tahun sebanyak 14 orang (18\%), selanjutnya usia 38-43 tahun sebanyak 11 orang (14\%), usia 44-49 tahun dan usia 50-55 tahun masing-masing sebanyak 1 orang atau sebesar $1 \%$ dari total sampel penelitian peneliti. Hal ini menunjukkan bahwa terdapat perbedaan jenjang usia yang cukup tinggi diantara pekerja seks komersial yang terdapat di lokalisasi Y, hal tersebut dikarenakan usia yang mendominasi para perempuan disana berkisar antara usia 2031 tahun yang jika di total sebanyak 51 orang dari 78 sampel atau jika dipersenkan menjadi sebesar $66 \%$.

Hasil pengkategorisasian data coping strategy dilakukan menggunakan software pengolahan data SPSS untuk mengetahui apakah individu menggunakan tipe coping strategy: emotional focused coping, problem focused coping atau tipe campuran. Pekerja seks yang termasuk tipe emotional focused coping sebanyak 9 orang $(11,5 \%)$, pekerja seks yang tipe problem focused coping sebanyak 19 orang $(24,4 \%)$, serta pekerja seks yang termasuk tipe campuran sebanyak 50 orang $(64,1 \%)$.

Hal diatas menjelaskan bahwa para pekerja seks komersial yang berlokasi di lokalisasi Y mempunyai coping strategy yang efektif, hal tersebut dikarenakan kebanyakan dari mereka memiliki tipe campuran untuk coping strategynya. Hal tersebut sesuai dengan pendapat Cohen (2005) yang menyebutkan individu yang memiliki kemampuan coping yang efektif apabila, mampu menerapkan strategy coping yang sesuai dengan kondisi individu bukan cenderung menggunakan tipe-tipe tertentu untuk menyelesaikan semua masalahnya.
Hasil pengkategorisasian data penyesuaian diri dilakukan berdasarkan perhitungan menggunakan kurve normal dengan mean 152,89 lalu standard deviasi penyesuaian diri sebesar 30,95 sehingga di dapat -1SD sebesar 121,95 dan +1SD sebesar 183,83 yang otomatis dijadikan skor patokan untuk mengetahui apakah penyesuian diri individu tergolong rendah, sedang atau tinggi. Pekerja seks dengan penyesuaian diri yang rendah berjumlah 10 orang $(12,8 \%)$, pekerja seks dengan penyesuaian diri yang sedang berjumlah 59 orang $(75,6 \%)$, dan pekerja seks yang memiliki penyesuaian diri tinggi berjumlah 9 orang $(11,5 \%)$.

Berdasarkan pengkategorisasian diatas dapat disimpulkan bahwa sebagian besar penyesuaian diri dari pekerja seks komersial yang berlokasi di lokalisasi Y tergolong dalam kategori sedang.

Setelah melakukan uji-uji yang telah dicantumkan pada pembahasan di bab-bab sebelumnya, maka peneliti menganggap bahwa penelitian ini telah mampu menjawab rumusan masalah serta tujuan penelitian yang telah diuraikan di bab 2, yaitu bertujuan untuk mengetahui hubungan penyesuaian diri dengan coping strategy pada pekerja seks komersial yang terjangkit infeksi menular seksual.

\section{DAFTAR PUSTAKA}

Cohen, Jay, R. Swerdik. Mark, E. (2005). Psychological testing and assessment: An introduction to test and measurement. New York: Mc Graw-Hill Company.

Devi, P. T. L. (2014). Gambaran kualitas hidup waria yang telah coming out. Studi kasus (tidak dipublikasikan). Program Studi Psikologi Fakultas Kedokteran Universitas Udayana.

Dian, F. (2008). Hubungan antara konsep diri dengan coping strategy pada developed kiddie dalam komunitas hacker di perguruan tinggi x Bandung. Skripsi (tidak dipublikasikan). Fakultas Psikologi Universitas Islam Bandung.

Fahmi, M. (1997). Kesehatan jiwa dalam keluarga, sekolah, dan masyarakat. Jakarta: Bulan Bintang.

Hasan, I. (1999). Pokok-pokok materi stastistika 2 (Statistik inferensif). Jakarta: Bumi Aksara.

Herawati, Y. E. (2007). Hubungan antara pengetahuan tentang penyakit menular seksual dan sikap terhadap seks bebas pada remaja akhir. Skripsi (tidak dipublikasikan). Semarang: Fakultas Psikologi Universitas Kristen Soegijapranata.

Himpsi. (2010). Kode etik psikologi indonesia. Jakarta: Pengurus Pusat Himpunan Psikologi Indonesia.

Kartono, K. (2011). Patologi sosial. Jakarta: PT. Raja Grafindo Persada.

Kristina, N. N. (2014 Agustus 15). Infeksi menular seksual (IMS) dan infeksi saluran reproduksi (ISR). Diambil dari Dinas Kesehatan Provinsi Bali: http://www.diskes.baliprov.go.id/id/INFEKSI-MENULARSEKSUAL--IMS--DAN-INFEKSI-SALURANREPRODUKSI--ISR-2 Diakses pada 20-4-2015

Koentjoro. (2004). On the spot: Tutur dari sarang pelacur. Yogyakarta: Tinta Kelompok Penerbit Qalam. 
Lazarus, R. S., \& Folkman, S. (1984). Coping and adaptation in: Gentry, w.d. handbook of behavioral medicine. New York/London: The Guildford Press.

Lazarus, R. S. (1991). Emotion and adaptation. New York: Oxford University Press.

Mukarom, R. S. (2012). Gambaran pengetahuan dan sikap wanita tuna susila terhadap infeksi HIV dan AIDS di Lokalisasi Kopeng Kabupaten Semarang. Jurnal Kebidanan Panti Wilasa, 3(1), 1-8.

Nazir, M. (1988). Metode penelitian cetakan ketiga. Jakarta: Ghalia Indonesia

Nasution, I. K., \& Sihaloho, N. (2012). Tahapan pengambilan keputusan menjadi pekerja seks komersial pada remaja puteri. Predicara, 1(1), 37-46.

Pearlin, L. A., \& Schooler, C. (1987). The structure of coping. Journal of Health and Social Behavior, 19(2), 2-21.

Pikiran Rakyat. (2013, Juni 17). Pekerja seks berperan besar dalam penyebaran HIV/AIDS. Diambil dari Pikiran Rakyat Online: http://www.pikiranrakyat.com/nasional/2013/06/17/239035/pekerja-seksberperan-besar-dalam-penyebaran-hivaids Diakses pada 4$7-2015$

Prastiwi, A. N. A. (2007). Kebutuhan-kebutuhan psikologis perempuan pekerja seks (Studi kasus di Komplek Wisata Bandungan Ambarawa). Skripsi (tidak dipublikasikan). Semarang: Fakultas Psikologi Universitas Katolik Soegijapranata.

Scheineders, A. A. (1999). Personal adjusment and mental health. New York: Holt, Reinheart and Winston Inc.

Setiawan, R. (2013). Persona pada pekerja seks komersial wanita di Lokalisasi Jarak Surabaya. Skripsi (tidak dipublikasikan). Malang: Fakultas Psikologi Universitas Brawijaya.

Suarjaya, K. (2013 Desember 3). Profil kesehatan Provinsi Bali 2012. Diambil dari Dinas Kesehatan Provinsi Bali: http://www.depkes.go.id/resources/download/profil/PROFI L_KES_PROVINSI_2012/17_Profil_Kes.Prov.Bali_2012.p df Diakses pada 20-4-2015.

Tempo. (2013, April 16). 40 juta PSK menghuni Lokalisasi di seluruh Indonesia. Diambil dari Tempo Nasional: http://www.tempo.co/read/news/2013/04/16/058473745/40Juta-PSK-Menghuni-Lokalisasi-di-Seluruh-Indonesia. Diakses pada 20-5-2015

Walgito, B. (1991). Psikologi sosial (suatu pengantar). Yogyakarta: Andi Offset.

White, R. W., \& Watt, N. F. (1981). The abnormal psychology. New York: John Wiley and Sons Inc

Wijaya, N. (2007). Hubungan antara keyakinan diri akademik dengan penyesuaian diri siswa tahun pertama sekolah asrama SMA Pangudi Luhur Van Lith Muntilan. Skripsi (tidak dipublikasikan). Semarang: Universitas Diponegoro.

Wikipedia. (2014, Agustus 5). Penyakit menular seksual. Diambil dari Wikipedia Ensiklopedia Bebas: http://id.wikipedia.org/wiki/Penyakit_menular_seksual. Diakses pada 5-8-2014 